\title{
今日のカラーテテレビジョ゙ャ (
}

\author{
Color Television Today
}

\author{
RCA 名誉副社長 V. K. ZWORYKIN \\ 東京工業大学講師 大河内 正陽 訳
}

受像機（第 14 图）において, 中間周波段の振幅特性 は平坦とされ，時間遅延は $42 \mathrm{Mc}$ まで一様である。第 2 検波のあとで, 信号は輝度と色度チャンネルに分割され る。輝度チャンネルの信号は副搬送波周波数附近で強く 减衰され，スプリアスな点図形の見え方を少くするよう にする。色度チャンネルでは, 帯域濾波器により映像信

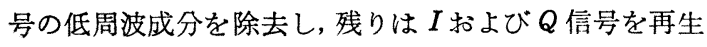
するための $90^{`}$ 位相差を持った復調器に加えられる。復 調器に用いる局部発振は, ゲート回路によって映像信号 から分離されたバーストにより，送像機の副搬送波発振 と同期される。適当な総合伝送特性を得るための低域濾 波器により色差信号 $E_{I^{\prime}}{ }^{\prime}$ および $E_{Q^{\prime}}$ を分離する。マトリ ックス回路はこれら 2 箇の信号を $E_{Y^{\prime}}$ と組合わして, 映 像再生装置飞打いて赤, 緑, 青成分の画像を生ずる 3 箇の 信号 $E_{R^{\prime}}, E_{G^{\prime}}{ }^{\prime}$ および $E_{B}{ }^{\prime}$ を合成する。これらを組合わせ てもとの天然色映像を再現するのである。

輝度信号の高周波成分が，誤差信号とし て色度チャンネル中に存在するということ は，注意すべきである。それらの成分は復 調器によって，極性が次々のフレームで変 る低周波信号へと変換される。したがって それらは 1 秒間に 15 の周期を持つスプ リアスな色度変化となる。さいわい, 眼つ フリッカーに対する知覚の限界周波数は, 色度变化に対するほうが輝度変化に対する より低いから，上のようなスプリアスな色 度変化が映像の質を害するようなことはな い。

カラー・テレビジョン方式について，以 上つような一般的検討を行ったのち, 終端 装置, すなわちカメラと, 映像の再生装置 をすっと詳しく検討することは興味あるこ とであろう。 カラー・ピックアップ装置は, スペクト
ル・レスポンスに関して、すべて同一の条件を満足しな ければならない。すなわち，与えられた波長の光に対す る赤, 緑, 青チャンネルの感度は, その波長の光に色合 させるのに必要な赤, 緑, 青の受像機の原色光源の強度 に比例しなければならない。この要求は, 単純な装置で はどんなるのを用いても正確には満足されることがな い。なぜなら，スペクトル光源が受像機原色（第 2 図） によって限定されるカラー三角形の外にあるからであ る。しかし通常の観察者が色彩の再生をすばらしいと思 う程度には，充分近似することができる。

この点を除けば, カラー・カメラの配列は, その用途 に大いに左右される。最も融通性に富み, しか子感度の よいカメラの形式は第 15 図に示したような中継対物レ ンズを持つイメージ・オルシコン・カメラである。これ はスタジオ用にも野外用にも用いられる。カメラ対物レ

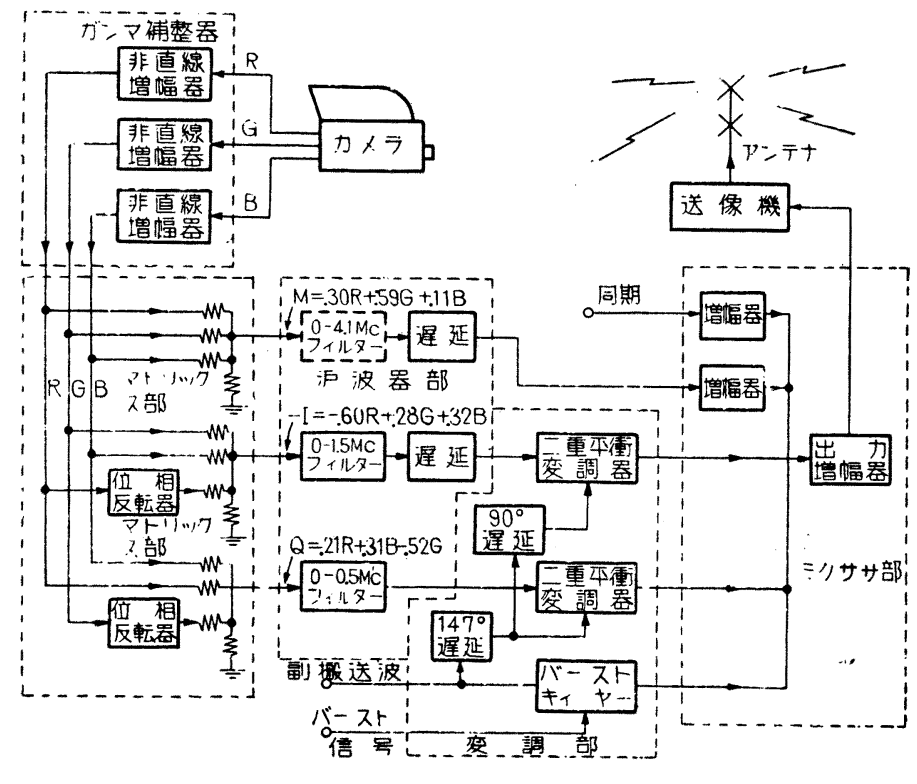

第 13 図カラー・テレビジョン送像機のブロック図 
ンズの焦点距離と, それに対応する写角 のいかんにかかわらず，ビーム分離系に 対し適当な空間を与えるために，一箇の 長焦点中継対物レンズがつけられている (第 16 図)。この中継対物レンズは, カ メラ対物レンズによってフィールド・レ ンズの面に形成された原色イメージを， 三つのイメージ・オルシコンの光電陰極 面の上に像として結ばせる。

中継対物レンズとイメージ・オルシコ ンとの中間で, 光線は赤, 緑, 青の成分 に分けられる。この操作は 2 箇のダイク ロイック・ミラーによって行われる。こ の鏡は本質的には干渉フィルターであっ て、あるスペクトル帯域を反射し, 残り の带域を最小の吸収損失で透過させる。

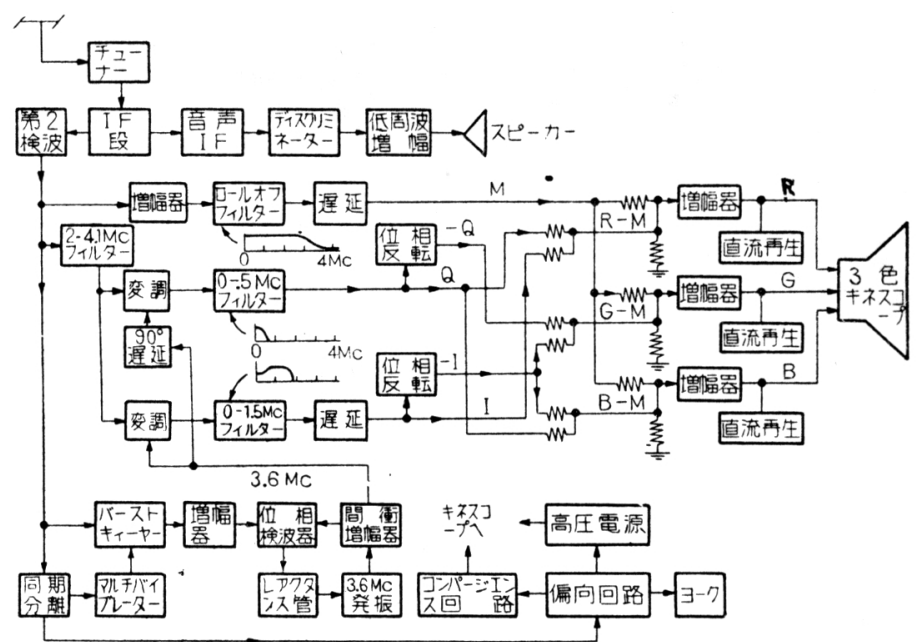

第 14 図カラー・テレピジョン受像機のブロック为 光線の通路にさらに㨉入されているカラーおよび中性フ イルターにより, 映像の白い部分に対して 3 箇のチャン ネルの信号振幅が同一となるように, 全装置のスペクト ル特性と感度とを望み通りに平衡させている。

3 箇の映像信号に対して, 正確な重ね合わせが保持さ れなければならないから, 走査パターンは 3 箇の光像に 対し同一で, 正確な位置にな计ればならない。これは, 3 箇のヨークに平行に帰電し，各管に整列コイルおよび 幅と傾斜の調節を付することによって行われる。その他 水平拈よび垂直シェーディング信号を用いて,イメージ ・オルシコンの光電陰極面上の感度のどんな不均一も補 視するようにする。

フィルム送像に対しても, 同様正確な重社合わせが必 要である。しかし，対象（すなわら伝送しようとするフ イルム) が固定面内にあるということのために, 光学系 はきわめて簡単にできる。その上，より高い輝度レベル を用いることができるから，小型ビディコンをイメージ ・オルシコンの代りに用いることができる。映像は, 間

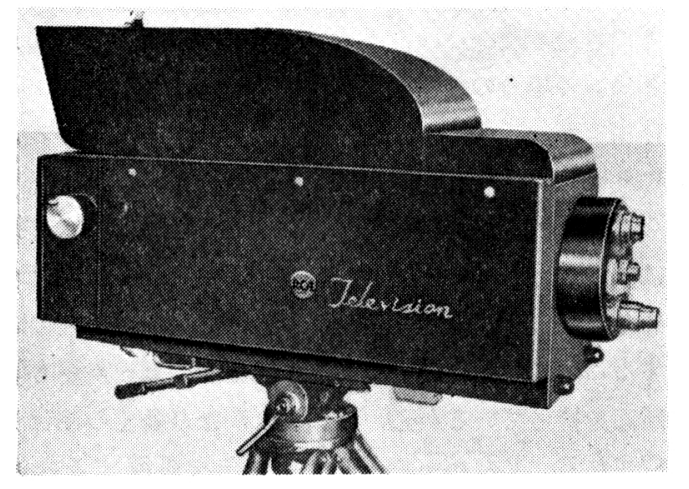

第 15 図カラー放送用のスタジオ及び野外用カメラ

歇式映写機によって, フィールドレンズの上に映し出さ

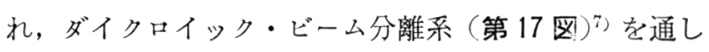
て, 三つのビディコンにより撮像される。ビディコンを 用いると装置が小型になる利点がある上に, 操作もずっ と簡単になる。

静止した映像の場合は, また簡単な非蓄積式の飛点ピ ックアップ方式を用いることができる（第18図）。走査 パターンが, 放送しよ5とするスライドの上に投映され, 通過した光が赤, 緑, 青の成分に分けられて, 3 箅の光 電子増培管の光電陰極にあたる。この方式では重社合わ せの問題は全く生じない。しかし一方, 飛点管からの光 は赤い成分が少いので, 赤信号に対する信号対雑音比が 比較的小さい傾向にある。さらにまた, 前置増幅器の特 性を飛点螢光体の残光性に対し補償する必要がある。

現在用いられている上述のカメラ方式の発達と平行し て, 単一管式カラー・カメラについての研究も行われて きた。これらによれば, 重ね合わせの問題を除くことが でき, カメラ構造 ${ }^{8}$ が極めて簡単化になる。その他, 研 究方向としては, ピックアップ点に回転フィルター円板 を付して普通のカメラを用いる方法, またカメラから直 接供給されたフィールド順次信号から, 必要な 3 箇の同 時カメラ信号を得るための変換器を用いる方法等が考光

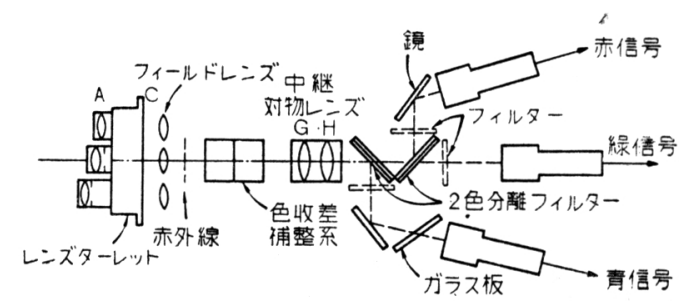

第 16 図 カメラの光学系配列 


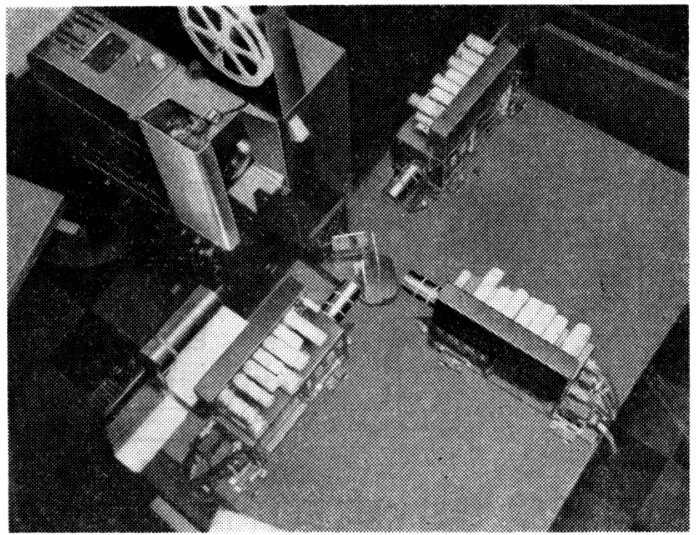

第 17 図 3 個のビディコンを用いた実験用フィルム 力x

られる。

しかしながら, 再生装置を簡単化することの方が, カ メラで同時式にするため 3 本を並列式にするより, るっ と経済的に重要なことである。したがって，初期に拈い ては, 同時式カラー受像機に, それぞれ赤, 緑, 青のス》 リーンを持つ 3 䈏のキネスコープを用いるのが普通の方 法であったが，現在直視式受像機には広く3色受像管が 用いられている。投映式受㑺機には，大口径反射式光学 系とともに3 箇の別々のキネスコープを用いることがま ず採用されている。このう式は劇場のカラー映写機用と しては，特に簡便であるが，その理由は 3 箇の映像がビ 一ム分割装置を中介とせず，映写スクリーン上に重畳し て投映されるからである。第 19 図は初期のカラー・テ レビジョン映写機を示したもので女るが，ごれによって 大きさ $9 \mathrm{ft} \times 12 \mathrm{ft}$ のスクリーン上に，良質の明るいカラ 一映像を再生できることが実証されている

Radio Corporation of America の研究所で行われて きた 3 色受像管に関する盛んな研究の成果として, カラ 一映像を再生できるきわめて多種の真空管が出現し た10)。それらの中で，3-電子銃シャドーマスク 3 色キネ

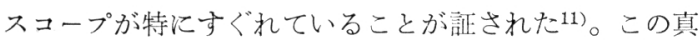
空管の原理を第 20 図に示した。

それぞれ赤, 緑, 青のカラー信号によって変調された 3 箇のビームが，共に 1 箇の偏向ヨークによって曲げら れ，有孔板の上に収歛される。この板中の孔は規則だっ

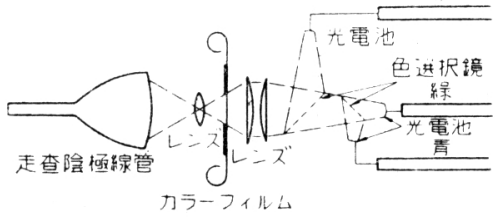

第 18 図静止映像用のフライングスポット走查装 置の原理

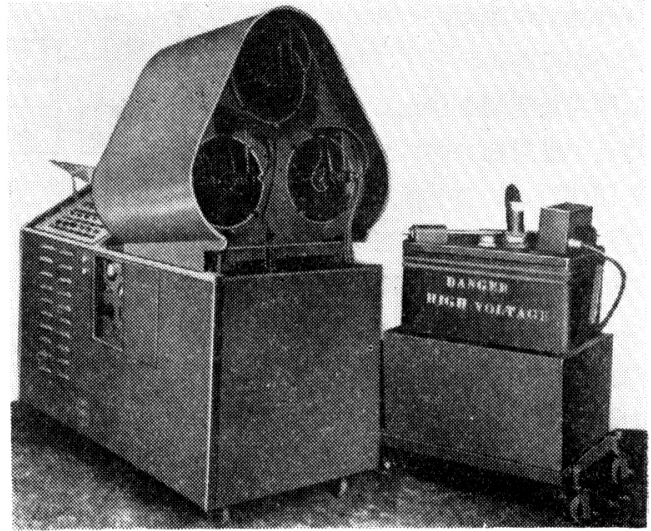

第 19 図劇場用カラー・テレビジョン

た六角形穴の集合からなっている。マスクの背後の螢光 面上沉は, おのおの赤, 緑, 青の点から成る 3 種の幾何 的に同形な行列が塗布されている。マ大少の孔が適当に 唒列されているので, マ大クの扎存通過した赤成分ビー ムの電子は赤の螢光点にの当り, 緑のビームは緑の螢 光点のみを, 青いビームの電子は青い螢光点のみを打つ ようになっている。初期の管では, キネスコープ外田器 の内側に，張力を加党た平らなマスクと螢光板とを挿入 していたが，曲率を持った受候板の内面に，曲率を持つ しっかりしたシャドー・マスクと溃光板を直接付着させ ることによって, 重量の減少と, 有効受像面積の増加を 得ることができた。

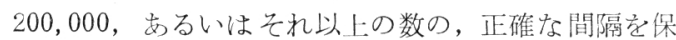
った有孔板と，營光面を作るのには，写真技術が応用さ れており，このスクリーン上の螢光点は， 0.001 in 程度 の誤差で，マスクの孔と一直線をなすよう並べられてい る。スクリーン自身，またはスクリーンを作るための原 板には, 感光性のエマルジョンを塗って技き,マスクを通 して，偏向板中のビーム中心の一つに位置した光源から の光虂出させる。このよ5汅して, ある一つの特定の 色に対する螢光点の配置が完成される。スクリーン自身 を露出させる場合には，この過程を 3 回絽返す。平面ス クリーンの場合のように原板が準備される場合は，1回 の露出で充分である。3 種の点行列が型によって, スク リーンに印刷され，型を印刷間に点間隔だけずらす。

シャドー・マスク管に执いて，マスクは第 3 の穴を打 つはずの電子流から，他の二つの行列を遮ざる役をす る。したがって，マスクは電子流の少くとも，2/3を吸 収することになる。実際には，偏向板中のビームが有限 の断面を持っているから，それよりかなり多くの割合が. 吸収される。したがって, 電子の損失を低減するため に，孔を電子レンズで置きがる案が，比較的早くに出 
されたのも不思議ではない12)。とくに，マスクを細い線 から成る格子に換え, 格子と電子銃陰極間の電位差の 3 倍の加速電位を螢光板と格子の間に加えれば, 電子ビー ムは, 鋭い線となってスクリーン上焦点を結ぶ。赤, 緑，青のビームのたどる一連の平行線が，スクリーン上 塗布された赤, 緑, 青の線状螢光体と合致するように できれば，その動作が本質上シャドー・マスク 3 色キネ スコープ類似したカラー受像管が得られる(第21図)。

線格子と線状スクリーンを用い，後段加速を持った電 子管子多少異なった螢光ストリップの配列を用いれば, また単一走査ビームで動作する13)。この目的のために， 互に絶縁された格子の奇数番目と偶数番目の線の間にカ ラー選択電圧が加えられる

もし交錯した線格子間に電圧を加えなければ電子は緑 の線状營光体のみを打つ。適当な大きさの正または負の 電圧を加觉れば，すべての電子がそれぞれ赤または青の 線状螢光体の方に偏向される。赤, 緑, 青の信号は, カラ 一切換電圧と同期して電子銃において選別される。解像 度を下げない上うにするには, カラー切換電圧の周波数 を副般送波周波数の程度, 一般にはとれ等しく選ぶ。 光出力の低下とカラー切換発振の輻射を除くため遮蔽の 必要なこととが，ここで述べた単一電子銃方式の欠点で ある。

3一電子銃方式においても，後段加速による集束によっ て得られるビームのよりよい利用能率は，ある代償を払 って得られるのである。すなわち，与えられたスポット の大きさに扎いて得られる最大のビーム電流は, 電子銃 の動作電圧を下げれば减少する。二次電子抽よび散乱電 子によるコントラストの低下が甚しくなる。そして最後 に，線格子は，曲率を持った映像面に直接塗布したスク

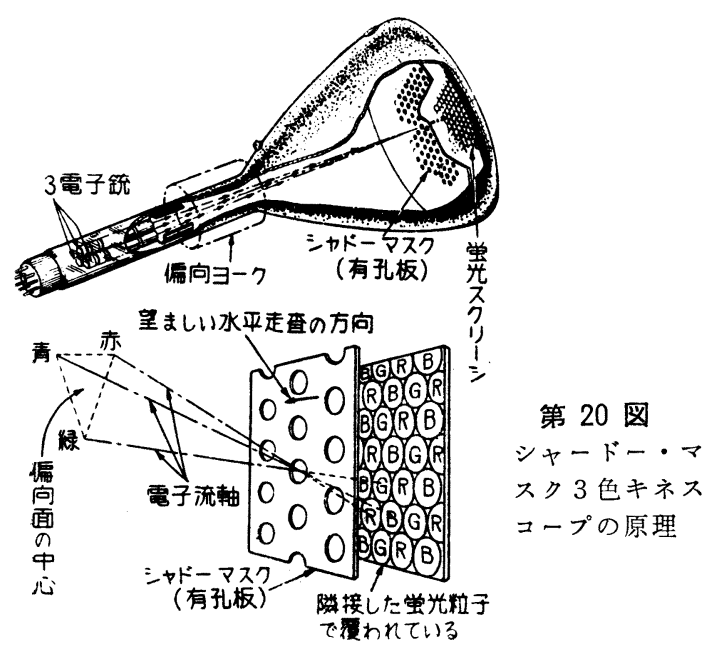

第 9 巻 第 7 号

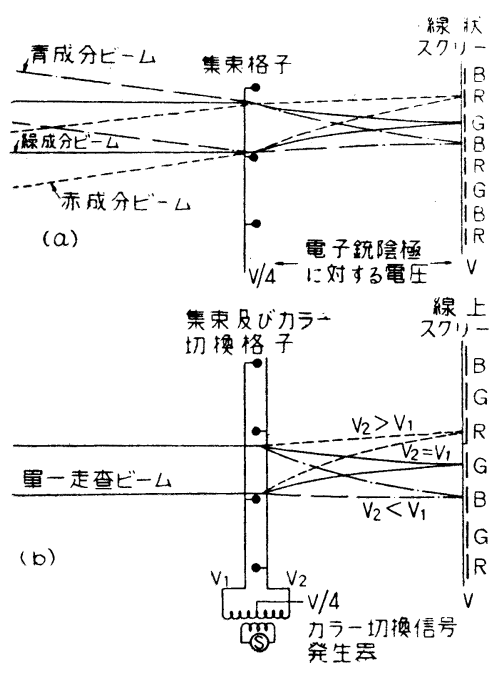

第 21 図 後段加速集束 を持つ(a) 3電子銃 (b) 単 一電子銃線状 スクリーン管 の原理

リーンには応用できない。

ぞの型のカラー受像管が結局最も満足なものであるか を, 今の段階で述べることは時期尚早である。しかしま た一方, 現在シャドー・マスク3色キネスコープによっ て, 相当満足なカラー映像を映し, また大規模な生産に も堪光る電子管が得られていることも確かである。この ように, 高性能なカラー・テレビジョン受像の技術的な 基礎は，すでに確固として築かれてきたのである。

カラー・テレビジョンの経済的な成功に重要な他の 因子としては, カラー・テレビジョン番組の録像及び再 生の迅速で安価な方法ということがある。カラーに怙け るフィルム録像も可能ではあるが，現在行われているモ ノクローム・テレビジョンでの白黒フィルム録像よりは 高価であり，また不安定でもある。このような状況にあ るから, カラー番組を磁気テープに録像する技術の開発 が特に重要となっている。磁気テープは化学処理を要せ ず, 無限に反覆使用でき, カラー・フィルムにくらべて 本質的に安価であるという利点を有している。

第 22 図は 1953 年 12 月 RCA によって公開実験され た，磁気テープによるカラー・テレビジョン信号の録像 および再生装置を示したものである15)。テープ駆動機構 の細部は第 23 図に, より明瞭に示されている。この実 験では, テープはキャプスタンによる非常に精密な一定 速度, $30 \mathrm{ft} / \mathrm{sec}$ で駆動された。巻取りリールと供給リー ルに施された帰還調整器により,テープは一定速度で送 られる。

テープ自体は酸化鉄を塗布した半时棺のセルローズ・ テープで, 厚さ約 0.002in である。赤, 緑, 青成分の映 像信号, 音声执よび同期信号に対し 5 本のトラックを有 している。第 1 段階で, 永久磁石消磁器により, 以前に 録像されている信号をテープから除き，録像に適するよ 
らにテープを磁化する。次にヘッドにより， $150 \mathrm{kC}$ 搬送 波を変調した音声を記録する。Bは四重へッドで，4本 の映像トラックを録像し，ヘッドC 号を再生するためのものである。音声再生用のへッドは キャプスタンの次にある。消去捄よび録像用ーッドが動 作しない場合には, テープが装置中を駆動されるごとに 録像されたプログラムが再生される。

録像㧍よび再生用のーッドの重要な部分は, それぞれ 磁化拈よびピック・アップ巻線を持った, 小型の馬蹄形 磁石からできている。録像へッドは，そのコイルに加光 られた映像信号振幅にしたがった強さで, ヘッドの間酇 を通過するテープ部分を磁化する。ヘッドは $3 \mathrm{Mc}$ の周 波数範囲に応動する。この周波数域の上限波長は, テー プに沿って約 0.0001 in の長さに対応する。これによっ ても, テープ駆動に精度がどれほど必要であるか, また ギャップがどれ汪ど狭くできているかについての概念が 得られるであろう。

実験では, 直径 17 in で $7000 \mathrm{ft}$ のテープ・リールによ り, $4 \frac{1}{2}$ 分間のプログラムが展示された。最近の研究で は, これより僅か大きい寸法のリールで, テレビジョン 番組の一単位として便利な $1 / 4$ 時間に, 番組時間を延長 することが目標とされている。

要するに, 現在顧客に対し趎力のある画面寸法を持っ た, 高性能のカラー受像管が製造されている。一実景, フィルム抢よぴスライドのカラー送像用のカメラ装置 が得られている。一そしてテープ録像炕よって, カラ —・テレビジョン番組の録像打よび再生に対する有効な 解決策が与兄られているということになる。これによっ てこのことと、コンパチブルなカラー・テレビジョン標準 の採用と相俟って, テレビジョン放送に次第にカラーの 採用が增加している事実に対する健全な基礎が作られて
きたとい方る。事実, 1954 年来アメリカに打いて, 101 の都市の 139 の放送局がカラー・プログラムのネット ワークに加入している。また 37 以上の放送局が, 自分 でカラー番組を編成する設備を持ち,さらに多数が同じ よらな設備を注交中である16)。このようにして, テレビ ジョンが初めて一本立ちとなった当時, 音に視覚を加兄 たいという望みがそうであったように, 色彩の次元を付 壮加光たいといら要求が, 一般に拡がる日もそう遠くは ないであろう。

しかし, カラー・テレビジョンの利用は, 放送のみに 限られていない。テレビジョンの多くの工業応用におい て, 色彩を付加することが重要な貢献となるであろう。 例光ば医学徒または開業医が，テレビジョンカメラによ って近距離からピックアップされた手術の天然色描出か らは, 白黒の同じ描出より, 女るいは手術見学席からの 直接見学よりもっと多くのことを学ぶことができる。

私設カラー・テレビジョン設備を作るについて生ずる 問題は, カラー・テレビジョン・スタジオ設備汇起るも のより, ある点では簡単であり, ある点では困難である。 すなわち, 私設備の簡易化は, それが放送標準に合致す る必要がないことにより, 可能とされる。他方小型で, 操作が簡単で, 低廉でなければならないというきびしい 要求があるので, 設計上, 上り困難な点がある。私設の 初期カラー・テレビジョン系統は, カメラの構成を簡単 にするため, 標準方式では順次方式を用いていた。一般 にこの方式はフィルター円板またはドラムを備えた，白 黒テレビジョン・カメラから成っている。しかし，この ような標準でない方式では, 画面の寸法や輝度が制限さ れるといら点があるだけでなく, 装置系統汇標準カラ 一受像機を用いることを妨げることにもなる。標準カラ 一受像機は, その性能が常に向上し, 価格も低廉になる ことが予想されるので, 後者の欠点は特 に重大である。

第 24 図は標準カラー・テレビジョン゙ 方式に必要とされるような赤, 緑, 青 3 箇の同時映像信号を発生する新しいカラ ー・テレビジョン・カメラを示したるの である。撮像管として 3 籄のビディコン を用いることにより，カメラの容積を， その寸法を普通の白黒スタジオ・カメラ に比しうる程度に隇じている。また, ビ ディコンでは調節箅所が隇小するので, カメラの操作が㰖単になる。

顕徽鏡と組合わして新しいカメラは顕 微鏡的対象物の天然色による, 便利な集 団観察を可能とするが，これは染色技術 


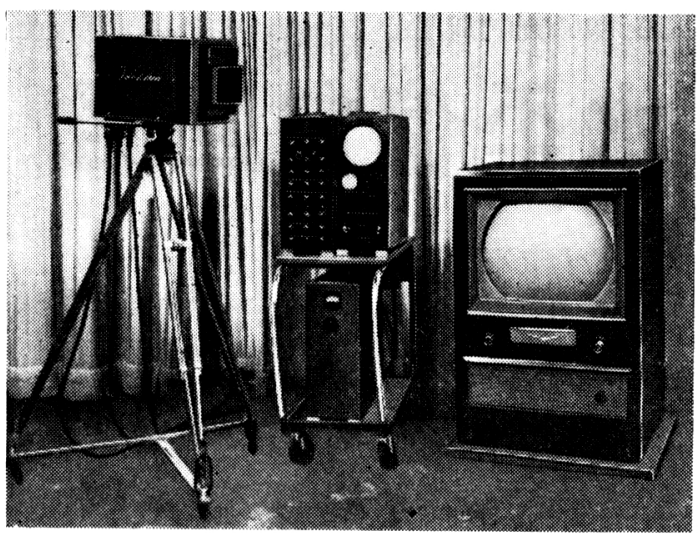

第 24 図 ビディコン・カラー・テレビジョン・カメラ

を教觉る上に確かに有利な方法である。対象物のより直 接なまた正確な確認に，色彩を利用することにより，教 育, 工業, 商業上カラー・カメラの数限りない他の用途 が，明らかにされている。

放送テレビジョンに拈けると同様, 私設テレビジョン に扎いても人は色盲であることを止め，今後，知識の蒦 得抢よび伝達に, 色彩が著しく貢献する場合にはいつ も, 色彩描出を利用することがいよいよ盛んになること が予想される。

\section{[引用文献]}

6 ) I. T. Sachtleben, D. J. Parker, G. L. Allem \& E. Kornstejn; "Image Orthicon Color Television Camera Optical System" RCA Review, Vol. 13, P. 27 33, 1952.

7) H.N. Kozanowski ; "3-Vidicon Color Film Camera" Broadcast News, Vol.79, P. 8 15, May-June, 1954.

8 ) P. K. Weimer, S.Gray, H. Borkan, S.A. Ochs \& H.C.ThoMPSวN; "The Tricolor Vidicon-an Experimental Camera Tube for Color Television" Presented at IRE National Convention, New York March. 24, 1955.

9 ) V.K. ZworykIN ; "Television'” J. Franklin Institute, Vol. P. $131 \sim 145,1947$.

10) E.W. Herold ; "Methods Suitable for Television Color Kinescopes" I. R. E. Vol. 39, P. 1177 1185, 1951.

11) H. B. LAw ; "A Three-gun Shadow-Mask Color Kinescope" I.R.E, Vol. 39, P. 1186 1194, 1951.

M. J. Grimes, A. C. Grimm \& J. F. Wil helm ; "Improvement in the RCA 'Three-Beam Shadow-Mask Color Kinescope," I.R.E, Vol. 42, p. 315 326, 1954.

N.F. FYLER, W.E. Rowe \& C.W. C AIN ; "The CBS Colortron : A Color Tube of Advanced Design ', I. R.E Vol. 42, P. 326 334, 1954

12) W $\mathrm{W}_{\text {ERNeR }} \mathrm{F}_{\text {LECHSIG }}$ ，フランス特許 $866,065,1941$ 年 6 月 16 日 参照

13) R. DRESSIER; “'The PDF Chromatron-a single or multi-gun tri-Color Cathode-ray tube, ' I. R.E, Vol. 41, P, 851 858, July, 1953.

J, D. Gow \& R. DorR ; ' Compatible Color Picture Presentation with the single gun Tricolor Chromatron." I.R.E, Vol. 42, P. 308 315, 1954 .

14 A.C.Schroeder, 米国特許 $2,446,791,1948$ 年 8 月 10 日発行参照

15) H.F.Clson, W.D. Houghton, A.R. Morgan, J. Zenel, M. ARzT, J. G. WoOdWard \& J.T. Fischer ; "A System for Recording and Reproducing Televition Signals", RCA Review, Vol.15, P. 3 17, 1954.

16) Television Factbook No.20, Spring, 1955, Washington. D.C.

\section{カラー・テレビ用天然色フィルム撮影時の被写体照明}

自然界に打汁る光域は 300: 1 程 度であるが，写真の光域では 100 :

1 である。一方テレビジョンのそれ は30：1であるから光域に関して自 然界々写真との間に成立つ関係が，

写真とテレビジョンの間にも成立つ わけである。したがって劇場用映画 として撮影したフィルムをテレビジ ョンで伝送した場合には, 過度に光 域が押し狭められる結果画の質は悪 くなり，中間調の再現には特別の技 術を必要とする。

subject contrast とはカメラが とらえている場面の性質のことであ り，例觉ば純白のシャツの上に真黑 な服を着た人の subject contrast は非常汇高いものになる。 subject - lighting contrast とは照明の仕 方によって出るコントラストのこと で，例党ば傾め上方から強く照明さ れた人の顔は, 碩から首にかけて濃 い蕻ができるであろう。
このとき額と碩の下との contrast はかなり大きな值となる。このcontrast のことを subject-lighting contrast と言っている。したがっ $\tau$ subject contrast の方か subject-lighting contrast よりも一般 に滛かに高い。

種々実験した結果劇場用のフィル ムには subject-lighting contrast は 4:1 でよいが, television 用の フィルムの場合は $2: 1$ がよく, こ のため key-light と fill-lightを適 当に使用して 2: 1 に下げるように 注意せねばならない。

また subject contrast の余り高 いときは衣裳を変える等して下げね ばならぬ。背景照明も画に深みを与 党るために適当に行わねばならね。 color television の場合には color balance を保つょうに 3channel の 利得の間に一定の関係を保つ必要か あるので, 用い得る光域は白黒 TV
の場合よりも更に狭くなる。照明の 強さが変っても color balance が崩 枕いようにする必要がある。イメ 一ジオルシコンの使い方も白黒式の 場合上りも細心の注意を払わないと color balance を乱す結果となる。 color television system は光域の限 界を光電変換特性の linear な範囲 に入れなければ balance が破れる。 また color television 用には subject lighting contrast $2: 1$ でよ い。もしこの值を $1: 1$ にすれば画 は甚だ平面的な感じがして深及がな くなる。color の場合も矢張り適当 に背景を照明する必要がある。

種々実験した結果 color filmを color television で伝送するときは (1) subject-lighting contrast は $2: 1$

（2）画に深みを与兄るために背景は 適当に照明すること

の二項目を推薦したい。

マスキングの技術が色の純度を上 げるために採られても，上記の二項 目は変化しないだろう。

(SMPTE, sept. 1954, vol. 63 (跲木一鉿木嘉郎) 